\title{
PARTIAL PURIFICATION OF ELICITORS FROM LENTINULA EDODES BASIDIOCARPS PROTECTING CUCUMBER SEEDLINGS AGAINST COLLETOTRICHUM LAGENARIUM
}

\author{
Robson M. Di Piero ${ }^{1}$; Nelson A. Wulff²; Sérgio F. Pascholati ${ }^{2 *}$ \\ ${ }^{1}$ Departamento de Fitotecnia, Centro de Ciências Agrárias, Universidade Federal de Santa Catarina, Florianópolis, SC, Brasil; \\ ${ }^{2}$ Departamento de Entomologia, Fitopatologia e Zoologia Agrícola, Escola Superior de Agricultura Luiz de Queiroz, \\ Universidade de São Paulo, Piracicaba, SP, Brasil
}

Submitted: July 01, 2004; Returned to authors for corrections: March 22, 2005; Approved: March 15, 2006

\begin{abstract}
The shiitake mushroom (Lentinula edodes) has been used in research involving the prevention and the control of human and plant diseases. In cucumber plants, treated with aqueous extracts from mushroom basidiocarps, there was a reduction in anthracnose severity caused by Colletotrichum lagenarium, and an increase in peroxidase activity in the leaves. With the aim of obtaining molecules of agronomic interest, the crude aqueous extract from $L$. edodes basidiocarp was fractioned with ammonium sulfate. The fraction corresponding to $40-80 \%$ of saturation (p40-80), the most effective in reducing anthracnose on cucumber cotyledons, was submitted to anion exchange chromatography (AEC). After AEC, six protein peaks were obtained and the peak $\mathrm{V}$, containing $34 \%$ of the proteins present in p $40-80$, induced peroxidase increase in the cucumber cotyledons besides reducing anthracnose severity. Separation of peak V proteins by SDS-gel electrophoresis revealed the presence of more than one band in the gel. Thus, a partial purification of elicitors present in the L. edodes basidiocarp was achieved.
\end{abstract}

Key words: shiitake, anthracnose, peroxidase

\section{INTRODUCTION}

Elicitors are molecules that stimulate any of a number of defense responses in plants, such as synthesis of phytoalexins and pathogenesis-related proteins (PR-proteins). Such responses occurs after the binding of elicitor molecules to receptors normally located on the plant cell surface, promoting a signal transduction pathway that will lead to the activation of one or more defense mechanisms. The first characterized elicitors were oligosaccharide fragments from fungal cell walls, including hepta- $\beta$-glucoside, oligochitin and oligochitosan (10).

Glucans, with the ability to induce the phytoalexin accumulation (glyceollin) in soybean tissues, were detected in the culture filtrates and on the mycelial walls of Phytophthora sojae, a phytopathogenic oomycete (2). Another glyceollin elicitor was isolated from autoclaved urediniospores of Hemileia vastatrix. This elicitor was water-soluble, heat-stable, resistant to the pronase treatment and sensitive to sodium metaperiodate. Besides, it had no affinity neither for Concanavalin-A lectin nor for the anion exchanger diethylaminoethyl-celulose (DEAEcellulose), suggesting to be a polysaccharide (9).

Microbial elicitors can also be glycoproteins, such as the ones synthesized by the yeast Saccharomyces cerevisae, that induce phenylalanine ammonia-lyase synthesis in tomato cell suspension (7) or phytoalexin accumulation in sorghum mesocotyls (25).

Recently, biologically active peptides have been purified and characterized. A protein-elicitor isolated from $P$. sojae induced phytoalexin synthesis in parsley plants (18). Several species of Phytophthora also produce other small proteins (around $10 \mathrm{kDa}$ ), known as elicitins. When applied in tobacco plants, elicitins increased PR-protein activity on the leaves and

*Corresponding Author. Mailing address: Departamento de Entomologia, Fitopatologia e Zoologia Agrícola, ESALQ, USP. 13418-900, Piracicaba, SP, Brasil. Tel.: (+5519) 3429-4124, Fax: (+5519) 3434-4839. E-mail: sfpascho@esalq.usp.br 
induced resistance against the plant pathogen $P$. parasitic var. nicotianae (19).

The mushroom Lentinula edodes, known as shiitake, produces polysaccharides and glycoproteins that activate the animal immune system and some of them show antibiotic activity too $(16,21,22)$. From shiitake basidiocarps, Kobayashi et al. (13) purified a protein that inhibited the infectivity of the Tobacco mosaic virus (TMV) on tobacco plants. That protein did not cause TMV aggregation and it did not exhibit a RNA hydrolyzing activity (11). The action of this L. edodes protein could have been on the plant by activating defense mechanisms, however, there are no reports about that.

In cucumber plants with three true leaves kept under greenhouse conditions, the basidiocarp aqueous extract from several isolates of $L$. edodes significantly reduced the disease caused by Colletotrichum lagenarium, and increased the peroxidase activity on the leaves (5). Thus, the aim of the present work was to obtain fractions from $L$. edodes fruiting bodies, showing biological activity towards disease reduction and peroxidase increase, by using the interaction cucumber- $C$. lagenarium.

\section{MATERIALS AND METHODS}

\section{The crude aqueous extract from $L$. edodes}

L. edodes basidiocarps (isolate LE 96/22) were obtained from the mushroom grown in Eucaliptus grandis and E. saligna trunks. To obtain the aqueous extract, dehydrated powder from basidiocarps was suspended into distilled water $\left(14 \mathrm{~mL} \cdot \mathrm{g}^{-1}\right)$ and, after $24 \mathrm{~h}$ incubation at $4^{\circ} \mathrm{C}$, the suspension was filtered through a common filter paper $\left(8 \mathrm{~g} \cdot \mathrm{cm}^{-2}\right)$ and centrifuged at $20,000 \mathrm{~g}$ for $25 \mathrm{~min}$. The supernatant obtained, after this procedure, was considered as the crude aqueous extract.

\section{Fractionation of crude aqueous extract from $L$. edodes basidiocarps}

The proteins present in $100 \mathrm{~mL}$ of crude aqueous extract were precipitated with ammonium sulfate in saturations from 0 to $20 \%, 20$ to $40 \%, 40$ to $60 \%, 60$ to $80 \%$ and 80 to $100 \%$. The precipitates were dissolved in $2 \mathrm{~mL}$ distilled water. After dialysis against distilled water $\left(4^{\circ} \mathrm{C}, 48 \mathrm{~h}\right.$, three changes), accomplished in membrane with a cut off of $6-8 \mathrm{kDa}$, the volume of each precipitate was adjusted to $4 \mathrm{~mL}$ with distilled water. The protein content in the samples was quantified according to the Bradford procedure (3). The samples were used in a bioassay to check the protection of cucumber seedlings against $C$. lagenarium.

\section{Bioassay with cucumber seedlings}

Seeds of cucumber (Cucumis sativus cv. Caipira Verde) were placed in trays containing Plantimax ${ }^{\circledR}$ substrate and kept inside a greenhouse. When the cotyledons were $3 \mathrm{~cm}$ in length, the seedlings were removed from the substrate, washed, drought in the air and immersed into the fractions during $5 \mathrm{~s}$, in a way where just the cotyledons were reached (14). The treated seedlings were placed inside glass tubes $(9.0 \mathrm{~cm}$ height $\times 1.4 \mathrm{~cm}$ diameter $)$ containing distilled water and kept in a growth chamber $\left(25^{\circ} \mathrm{C} ; 12\right.$ $\mathrm{h}$ light period) until the end of the experiment. Three days later, the cotyledons were inoculated with $C$. lagenarium $\left(1 \times 10^{5}\right.$ spores. $\mathrm{mL}^{-1}$ ), by spraying. Each treatment had four replicates and a replicate was represented by four seedlings. The bioassay was evaluated 5 days after the inoculation, by estimating the disease severity visually, and expressed as percentage.

After the evaluation, the protein fractionation was made from a $275 \mathrm{~mL}$ sample of crude aqueous extract of L. edodes (isolate LE 96/22), by using ammonium sulfate in saturations from 0 to $40 \%, 40$ to $80 \%$ and 80 to $100 \%$. Each precipitate was dissolved in $6 \mathrm{~mL}$ of distilled water, dialyzed, and the final volume adjusted to $14 \mathrm{~mL}$ with distilled water. The suspended materials were then evaluated for cucumber protection based upon the seedling bioassay.

\section{Chromatography of the precipitate corresponding to $40-80 \%$ of saturation (p40-80)}

A sample of the precipitate $\mathrm{p} 40-80$, containing $18 \mathrm{mg}$ protein, was submitted to cation exchange chromatography (CEC) in a column $(2.5 \times 10 \mathrm{~cm})$ filled with carboxy-methyl cellulose (CMCellulose) and equilibrated with $10 \mathrm{mM}$ acetate buffer (pH 5.0). The unbound material was eluted in equilibration buffer at a flow rate of $3 \mathrm{~mL} \cdot \mathrm{min}^{-1}$ and the bound material was displaced by increasing $\mathrm{NaCl}$ concentration $(0$ to $1.0 \mathrm{M})$ in the same buffer.

Another sample of p40-80, containing $24 \mathrm{mg}$ protein, was submitted to anion exchange chromatography (AEC) in a column $(2.5 \times 15 \mathrm{~cm})$ filled with DEAE-Cellulose and equilibrated with 25 $\mathrm{mM}$ sodium phosphate buffer ( $\mathrm{pH}$ 6.0). The unbound material was eluted in equilibration buffer at a flow rate of $2.5 \mathrm{~mL} \cdot \mathrm{min}^{-1}$ and the bound material was displaced by $\mathrm{NaCl}$ in the same buffer, by increasing the salt concentration $(0,0.2,0.4,0.6,0.8$ and $1.0 \mathrm{M}$ ), through a step-wise procedure. The collected fractions were pooled according to their profiles at $280 \mathrm{~nm}$, dialyzed three times against water $(12 \mathrm{~h}$ intervals with $7 \mathrm{~L}$ of distilled water at $4^{\circ} \mathrm{C}$ ), concentrated with polyethylene-glicol 20,000 to a final volume of $5 \mathrm{~mL}$ and tested in the bioassay with cucumber seedlings.

\section{Peroxidase activity in cucumber cotyledons}

Cucumber seedlings, obtained as mentioned above, had their cotyledons immersed into the fractions of interest (peaks obtained from AEC). The seedlings were kept inside glass tubes containing distilled water during 3 days, under growth-chamber conditions $\left(25^{\circ} \mathrm{C} ; 12 \mathrm{~h}\right.$ light period), when the cotyledons were harvested. Four replicates were undertaken by treatment, and a replicate was represented by three cotyledons.

The samples were frozen in liquid nitrogen, homogenized in $4.0 \mathrm{~mL}$ of $100 \mathrm{mM}$ phosphate buffer (pH 6.0) (extraction buffer) 
and centrifuged at $20,000 \mathrm{~g}$ by $30 \mathrm{~min}$, at $4^{\circ} \mathrm{C}$. The supernatants were used to evaluate peroxidase activity as well as the total protein content. A $0.1 \mathrm{~mL}$ sample of the supernatant was added to $3 \mathrm{~mL}$ of the assay mixture, which consisted of extraction buffer, $0.1 \mathrm{M} \mathrm{H}_{2} \mathrm{O}_{2}$ and $0.25 \%$ (v/v) guaiacol. The reaction was carried out at $30^{\circ} \mathrm{C}$ during $4 \mathrm{~min}$, and the absorbance at $470 \mathrm{~nm}$ was recorded every $20 \mathrm{~s}$, starting $1 \mathrm{~min}$ after the addition of the supernatant to the mixture. Protein content in the samples was evaluated by the Bradford procedure (3). Enzyme activity was expressed in units of absorbance at $470 \mathrm{~nm} / \mathrm{mg}$ protein / min (Abs/mg prot/min).

\section{SDS-polyacrylamide gel electrophoresis (SDS-PAGE) of the biologically active fractions}

Samples of the precipitate p40-80 and of the peak V, one of the peaks obtained after the p40-80 fractionation by AEC, were submitted to electrophoresis in polyacrylamide gel $(8 \mathrm{x}$ $8 \mathrm{~cm}$ ) under dissociating conditions, using the procedure described by Laemmli (15). The running gel was prepared with $10 \%$ acrylamide, while the stacking gel with $4 \%$. The electrophoresis was performed at $4^{\circ} \mathrm{C}$, under $100 \mathrm{~V}$, during 2 h. Bands were visualized by gel staining with Coomassie Brilliant Blue R250 (Sigma). Apparent molecular weight was determined using a kit from Amersham Pharmacia Biotech (range between 29.0 and $116.0 \mathrm{kDa}$ ).

\section{RESULTS AND DISCUSSION}

L. edodes exhibits a protecting effect on cucumber plants against $C$. lagenarium under greenhouse conditions, depending upon the concentration of the basidiocarp aqueous extract used (5). The crude extract at $20 \%$ (v/v) also increased peroxidase activity systemically in cucumber leaves. Peroxidases are considered as resistance biochemical markers for this plantpathogen interaction (4).

In the present investigation, a partial purification of peroxidase elicitors in cucumber seedlings from $L$. edodes basidiocarps was obtained, by using fractioned precipitation of molecules with ammonium sulfate and anion exchange chromatography.

In the first fractionation of the proteins present in the crude aqueous extract of $L$. edodes, utilizing ammonium sulfate, all the precipitates obtained reduced anthracnose severity in cucumber seedlings. However, the ones ranging from 20 to $80 \%$ saturation were the most effective (data not shown). Considering the relative efficiency and the protein concentration of the precipitates, a new separation of the proteins of $L$. edodes was made with ammonium sulfate, now in saturations from 0 to $40 \%$, 40 to $80 \%$ and 80 to $100 \%$. The treatment of cucumber seedlings with those materials revealed that the best protecting effect was obtained with the precipitate p40-80 (Table 1), which was then submitted to chromatography.
During the CEC, there was no binding of the molecules present in the precipitate $\mathrm{p} 40-80$ to the CM-Cellulose resin (data not shown). On the other hand, six peaks were obtained when a sample containing $24 \mathrm{mg}$ of protein from $\mathrm{p} 40-80$ was submitted to AEC, as it is illustrated by Fig. 1. This indicates that according to our experimental conditions, active molecules present on

Table 1. Effect of the fractions, obtained with ammonium sulfate precipitation of crude aqueous extract of Lentinula edodes basidiocarps, on anthracnose severity in cucumber seedlings.

\begin{tabular}{ccc}
\hline Treatment & $\begin{array}{c}\text { Protein content } \\
(\mathrm{mg} / \mathrm{mL})\end{array}$ & $\begin{array}{c}\text { Anthracnose } \\
\text { severity }(\%)^{1}\end{array}$ \\
\hline Water & - & $52.0 \pm 6.4 \mathrm{a}$ \\
$\mathrm{p} 0-40^{2}$ & 1.21 & $21.0 \pm 10.2 \mathrm{bc}$ \\
$\mathrm{p} 40-80$ & 3.63 & $6.0 \pm 2.2 \mathrm{c}$ \\
$\mathrm{p} 80-100$ & 0.27 & $39.0 \pm 11.2 \mathrm{ab}$ \\
Supernatant & & $50.0 \pm 2.2 \mathrm{a}$ \\
Crude extract $^{3}$ & 0 & $17.0 \pm 9.4$ \\
\hline
\end{tabular}

${ }^{1}$ Data represent the means of four replicates \pm standard errors. Means followed by the same letter are not significantly different (Tukey's test, $\mathrm{P} \leq 0.05) ;{ }^{2}$ Precipitate obtained in function of the ammonium sulfate range (\%); ${ }^{3}$ Refers to the phase obtained after the total precipitation of the proteins present in the crude extract.

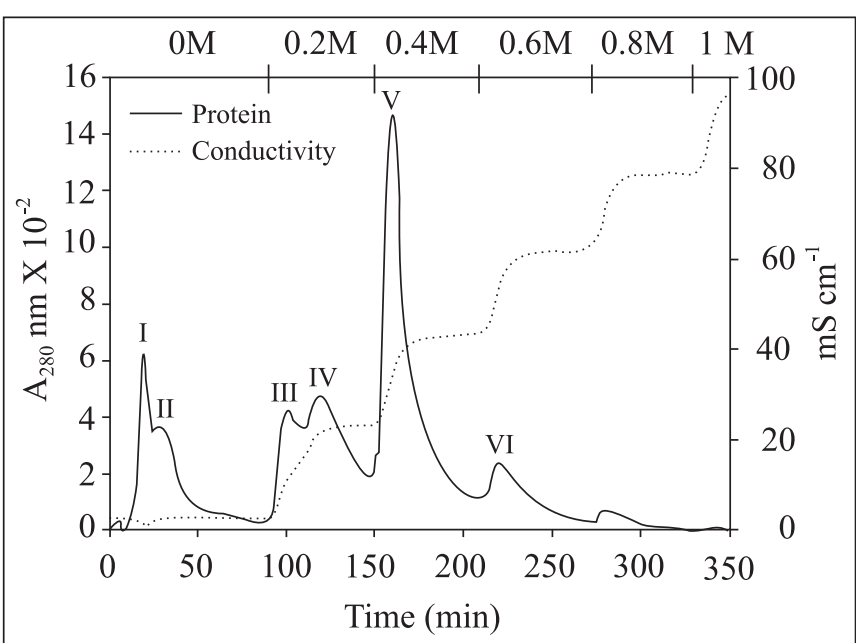

Figure 1. Anion exchange chromatography of precipitate $\mathrm{p} 40$ 80 obtained from the crude aqueous extract of Lentinula edodes fruiting bodies. A sample containing $24 \mathrm{mg}$ of protein was applied into a column filled with DEAE-Cellulose. Chromatography was performed with $25 \mathrm{mM}$ phosphate buffer ( $\mathrm{pH}$ 6.0), in a flow rate of $2.5 \mathrm{~mL} \cdot \mathrm{min}^{-1}$, and the bound material was eluted with $\mathrm{NaCl}$ in the same buffer, through a step-wise procedure (upper $\mathrm{X}$-axis values). 
p40-80 fraction have a negative net charge, showing affinity only to anionic resin. By incrementing a cationic chromatographic step did not result in further purification and higher specific activity.

In the first bioassay, when the material present in the six peaks was applied onto cucumber seedlings, only peak V promoted a significant control of anthracnose (Table 2). In a second one, the peaks were obtained from a new lot of $L$. edodes fruiting bodies, and each peak was used with the same quantities of proteins present in the first bioassay. In this experiment, the precipitate p40-80 was also evaluated to compare its activity directly to the activity of the peaks. None of the peaks, including peak $\mathrm{V}$, were effective in reducing the anthracnose severity, while the precipitate $\mathrm{p} 40-80$ reduced disease in approximately $50 \%$ (data not shown).

In terms of elicitor activity, the peaks III and V as well as the precipitate p40-80 (Table 3) increased peroxidase activity in cucumber cotyledons in relation to the ones treated with distilled water (Table 3). The experiment with peroxidases was accomplished twice and they showed the same general results.

The ammonium sulfate precipitate p40-80 was fractionated into 6 bands after SDS-PAGE. In turn, Peak V, an inducer of peroxidase activity (Table 3), derived from p40-80 (Fig. 1), contained only two protein bands from fraction p40-80 (Fig. 2). Since one of these proteins $(29 \mathrm{kDa})$ was not seen in peak V, derived from a second purification experiment from a different lot of basidiocarps (lot 2), it can be considered that the $29 \mathrm{kDa}$ protein is the candidate to induce resistance in cucumber to anthracnose by the activation of peroxidases.

Protein or glycoprotein elicitors have been isolated from microorganisms, and some of those are able to induce resistance

Table 2. Effect of pooled fractions (peaks), obtained from the fractionation of the precipitate $\mathrm{p} 40-80$ of Lentinula edodes by anion exchange chromatography (Fig. 1), on anthracnose severity in cucumber seedlings ${ }^{1}$.

\begin{tabular}{ccc}
\hline Treatment & $\begin{array}{c}\text { Protein content } \\
(\mathrm{mg}) \text { in 5 mL }\end{array}$ & $\begin{array}{c}\text { Anthracnose } \\
\text { severity }(\%)^{1}\end{array}$ \\
\hline Water & - & $26.0 \pm 12.0$ \\
PeakI & 1.18 & $13.0 \pm 4.0$ \\
Peak II & 0.30 & $16.0 \pm 5.0$ \\
Peak III & 1.25 & $17.0 \pm 6.0$ \\
Peak IV & 1.74 & $10.0 \pm 3.0$ \\
Peak V & 8.20 & $8.5 \pm 1.2^{*}$ \\
Peak VI & 0.72 & $18.0 \pm 7.0$ \\
\hline
\end{tabular}

${ }^{1} \mathrm{~A}$ sample equivalent to $24 \mathrm{mg}$ from $\mathrm{p} 40-80$ was applied into the chromatography column; ${ }^{2}$ Data represent the means of four replicates \pm standard errors. ${ }^{*}$ Treatment significantly different from the control (seedlings treated with water) by Dunnett's test $(\mathrm{P} \leq 0.05)$.
Table 3. Peroxidase activity in cucumber seedlings treated with the preparations present in peaks obtained from the fractionation of the precipitate p40-80 of Lentinula edodes by anion exchange chromatography.

\begin{tabular}{ccc}
\hline Treatment & $\begin{array}{c}\text { Protein content } \\
(\mathrm{mg}) \text { in 5 mL }\end{array}$ & $\begin{array}{c}\text { Peroxidase activity } \\
(\text { Abs/ mg prot/ min })^{1}\end{array}$ \\
\hline Water & - & $10.1 \pm 1.8$ \\
Peak III & 1.5 & $15.4 \pm 1.5^{*}$ \\
Peak IV & 2.0 & $12.9 \pm 3.7$ \\
Peak V & 8.0 & $15.7 \pm 3.1^{*}$ \\
Peak VI & 0.7 & $10.7 \pm 1.4$ \\
p40-80 & 8.0 & $15.9 \pm 3.5^{*}$ \\
\hline
\end{tabular}

${ }^{1}$ Data represent the means of four replicates \pm standard errors. *Treatment significantly different from the control (seedlings treated with water) by Dunnett's test $(\mathrm{P} \leq 0.05)$; ${ }^{2}$ Precipitate obtained from fractionation the crude aqueous extract of L. edodes basidiocarps with ammonium sulfate, and corresponding to $40-80 \%$ of saturation.

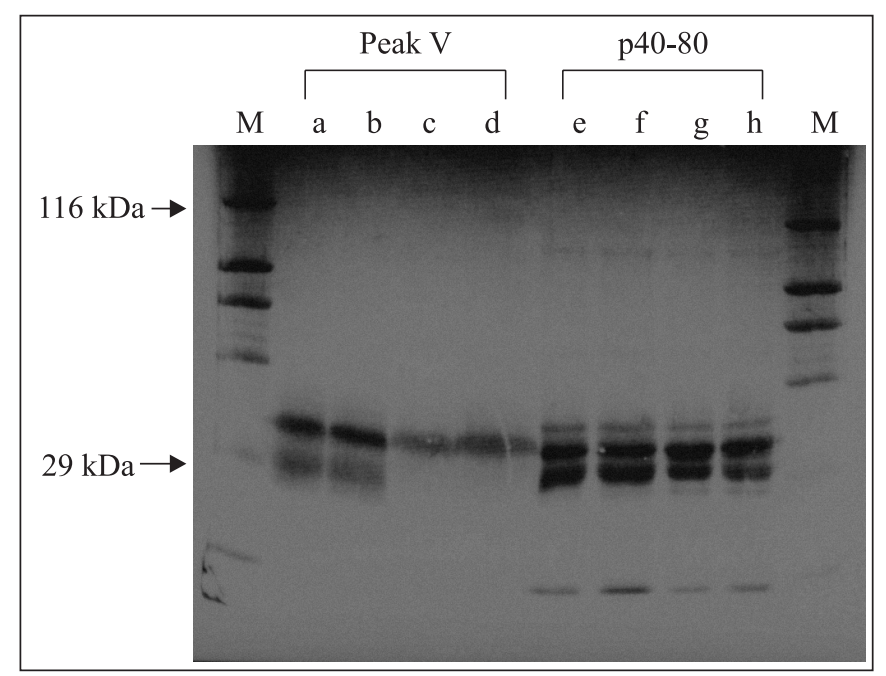

Figure 2. SDS-polyacrylamide gel electrophoresis of peak V and precipitate p40-80 from Lentinula edodes (isolate LE 96/ 22). The samples were obtained from two different lots of basidiocarps. Lot 1 - a, b, e, f; lot 2 - c, d, g, h. Quantities of protein applied: $28 \mu \mathrm{g}$ in (a) and (c), $35 \mu \mathrm{g}$ in (b) and (d), $50 \mu \mathrm{g}$ in (e) and (g), $70 \mu \mathrm{g}$ in (f) and (h). M = molecular marker.

in plants against pathogens. It is the case of the glycoprotein purified from the mycelial walls of Pyricularia oryzae, causal agent of the rice blast (20). The previous treatment of rice leaves with the elicitor increased peroxidase, cinamil-alcohol desidrogenase and lipoxigenase activities and reduced disease symptoms in the treated leaves. 
The commercial use of a protein-elicitor started with the discovery of harpin, a $44 \mathrm{kDa}$ protein rich in glicin and heatstable. The harpin is synthesized by Erwinia amylovora, Pseudomonas syringae and others plant-pathogenic bacteria, and represents a pathogenicity factor for those microorganisms during the interaction with their hosts. On other hand, harpin causes a hypersensitive reaction (HR) when it is infiltrated into the intercellular space of non-host species $(1,24)$. The foliar application of harpin does not cause a visible HR, but it activates plant defense responses, inducing systemic resistance in Arabidopsis thaliana against $P$. syringae pv. tomato (6), in cucumber plants against Gliocladium sp., in tomato plants against Ralstonia solanacearum (23), and in bell pepper plants against Beet curly top virus (12). These results stimulated the company EDEN Bioscience to develop a commercial product named Messenger ${ }^{\circledR}$, a resistance inducer having $3 \%$ of harpin as the active ingredient. In the case of elicitors of different natures, some commercial products were already developed like Agromos ${ }^{\circledR}$, based on mannan-oligosaccharides isolated from the $S$. cerevisiae cell wall, and Elexa®, where chitosan is the active ingredient.

Regarding L. edodes, peak V contains $34 \%$ of the proteins present in the precipitate p40-80 (Table 2), and approximately $15 \%$ of the proteins present in the crude aqueous extract from basidiocarps. Peroxidase activity in cucumber was similar in seedlings treated with peak V or precipitate p40-80 (Table 3), showing a progress in the purification of the elicitors present in L. edodes basidiocarps. However, although peak III also induced the same level of peroxidases as peak V (Table 3), it did not reduce anthracnose severity in the same way. This indicates that peroxidases are components of the defense responses of plants, and can even be considered as a marker for resistance (17), but do no act alone. There should be other defenses being activated by peak V, since defense is a multifunctional component in plants (7).

New studies involving the application of the fractions of interest in plants could indicate the viability of obtaining commercial products from the shiitake mushroom, in an attempt to control plant diseases in a healthy and ecological-safe way.

\section{RESUMO}

\section{Purificação parcial de elicitores a partir de basidiocarpos de Lentinula edodes protegendo plântulas de pepino contra Colletotrichum lagenarium}

O cogumelo shiitake (Lentinula edodes) vem sendo utilizado com objetivos de prevenir e controlar doenças em humanos e em vegetais. $\mathrm{O}$ tratamento com o extrato aquoso de basidiocarpos do cogumelo propiciou uma redução significativa na severidade da antracnose em plantas de pepino, provocada por
Colletotrichum lagenarium, e um aumento na atividade de peroxidases nos tecidos foliares. Desse modo, com o objetivo de obter moléculas de interesse agronômico destinadas à proteção de plantas, o extrato aquoso bruto de basidiocarpos de L. edodes foi fracionado inicialmente com sulfato de amônio. A fração correspondente a 40-80\% de saturação (p40-80) foi a mais efetiva em reduzir a antracnose em cotilédones de pepino, sendo então submetida à cromatografia de troca aniônica (CTA). Após a CTA, seis picos protéicos foram obtidos, e o pico $\mathrm{V}$, contendo em média 34\% das proteínas presentes em p40-80, provocou o acúmulo de peroxidases nos cotilédones de pepino, bem como reduziu a antracnose. A separação eletroforética das proteínas do pico $\mathrm{V}$ revelou a presença de mais de uma banda no gel de poliacrilamida. Portanto, estes procedimentos resultaram na purificação parcial de elicitores presentes no basidiocarpo de L. edodes.

Palavras-chave: shiitake, antracnose, peroxidases

\section{REFERENCES}

1. Adam, A.L.; Pike, S.; Hoyos, M.E.; Stone, J.M.; Walker, J.C.; Novacky, A. Rapid and transient activation of a myelin basic protein kinase in tobacco leaves treated with harpin from Erwinia amylovora. Plant Physiol., 115, 853-861, 1997.

2. Ayers, A.R; Ebel, J.; Valent, B.; Albersheim, P. Host-pathogen interactions. X - Fractionation and biological activity of an elicitor isolated from the mycelial walls of Phytophthora megasperma var sojae. Plant Physiol., 57, 760-765, 1976.

3. Bradford, M.A. A rapid and sensitive method for the quantitation of microgram quanties of protein utilizing the principle of protein-dye binding. Anal. Biochem., 72, 248-254, 1976.

4. Dean, R.A.; Kuc, J. Rapid lignification in response to wouding and infection as a mechanism for induced systemic protection in cucumber. Physiol. Mol. Plant Pathol., 31, 69-81, 1987.

5. Di Piero, R.M.; Pascholati, S.F. Indução de resistência em plantas de pepino contra Colletotrichum lagenarium pela aplicação de extratos de basidiocarpos de Lentinula edodes e de Agaricus blazei. Summa Phytopathologica, 30, 243-250, 2004.

6. Dong, H.; Delaney, T.P.; Bauer, D.W.; Beer, S.V. Harpin induces disease resistance in Arabidopsis through the systemic acquired resistance pathway mediated by salicylic acid and NIM1 gene. Plant J., 20, 207-215, 1999.

7. Glazebrook, J. Contrasting mechanisms of defense against biotrophic and necrotrophic pathogens. Ann. Rev. Phytopathol., 43, 205-227, 2005.

8. Grosskopf, D.G.; Felix, G.; Boller, T. A yeast-derived glycopeptide elicitor and chitosan or digitonin differentially induce ethylene biosynthesis, phenylalanine ammonia-lyase and callose formation in suspension-cultured tomato cells. J. Plant Physiol., 138, 741 746, 1991

9. Guzzo, S.D.; Moraes, W.B.C. Purificação e caracterização parcial de um elicitor de fitoalexina em soja, a partir de urediniosporos de Hemileia vastatrix. Fitopatol. Bras., 22, 396-402, 1997.

10. Hahn, M. G. Microbial elicitors and their receptors in plants. Annu. Rev. Phytopathol., 34, 387-412, 1996.

11. Hiramatsu, A.; Kobayashi, N.; Osawa, N. Properties of two inhibitors of plant virus infection from fruiting bodies of Lentinus edodes and from leaves of Yucca recurvifolia Salisb. Agric. Biol. Chem., 51, 897-904, 1987.

12. Jones, J. Harpin. Pestic. Outlook, 12, 134-135, 2001. 
13. Kobayashi, N.; Hiramatsu, A.; Akatsuka, T. Purification and chemical properties of an inhibitor of plant virus infection fom fruiting bodies of Lentinus edodes. Agric. Biol. Chem., 51, 883-890, 1987.

14. Labanca, E.R.G. Purificação parcial de elicitores presentes em Sacharomycces cerevisiae: atividade como indutores de resistência em pepino contra Colletotrichum lagenarium e da síntese de gliceolinas em soja. Piracicaba, 2002, 107p. (Dissertação. Mestrado. Escola Superior de Agricultura "Luiz de Queiroz". USP).

15. Laemmli, U.K. Cleavage of structural proteins during the assembly of the head of bacteriophage T4. Nature, 227, 680-685, 1970.

16. Mizuno, T. Bioactive biomolecules of mushrooms: food function and medicinal effect of mushroom fungi. Food Rev. Int., 11, 7-21, 1995.

17. Nawar, H.F.; Kuti, J.O. Wyerone acid phytoalexin synthesis and peroxidase activity as markers for resistance of broad beans to chocolate spot disease. J. Phytopathol., 151, 564-570, 2003.

18. Parker, J.E.; Schulte, W.; Hahlbrock, K.; Scheel, D. An extracellular glycoprotein from Phytophthora megasperma f. sp. glycinea elicits phytoalexin synthesis in cultured parsley cells and protoplasts. Mol. Plant-Microb. Interact., 4, 19-27, 1991.

19. Ricci, P.; Trentin, F.; Bonnet, P.; Venard, P.; Mouton-Perronnet, F.; Bruneteau, M. Differential production of parasiticien, an elicitor of necrosis and resistance in tobacco, by isolates of Phytophthora parasitica. Plant Pathol., 41, 298-307, 1992.

20. Schaffrath, U.; Scheinpflug, H.; Reisener, H.J. An elicitor from Pyricularia oryzae induces resistance responses in rice: isolation, characterization and physiological properties. Physiol. Mol. Plant Pathol., 46, 293-307, 1995.

21. Sugano, N.; Hibino, Y.; Choji, Y.; Maeda, H. Anticarcinogenic actions of water-soluble and alcohol insoluble fractions from culture medium of Lentinus edodes mycelia. Cancer Lett., 17, 109-114, 1982.

22. Suzuki, F.; Suzuki, C.; Shimomura, E.; Maeda, H.; Fujii, T.; Ishida, N. Antiviral and interferon-inducing activities of a new peptidomannan, KS-2, extracted from culture mycelia of Lentinus edodes. J. Antibiotics, 32, 1336-1345, 1979.

23. Wei, Z.M.; Beer, S.V.; Bonn, W.G. Harpin from Erwinia amylovora induces plant resistance. Acta Hortic., 411, 223-225, 1996.

24. Wei, Z.M.; Laby, R.J.; Zumoff, C.H.; Bauer, D.W.; He, S.Y.; Collmer, A.; Beer, S.V. Harpin, elicitor of the hypersensitive response produced by the plant pathogen Erwinia amylovora. Science, 257, 85-88, 1992.

25. Wulff, N.A.; Pascholati, S.F. Partial characterization of sorghum phytoalexin elicitors isolated from Saccharomyces cerevisiae. Fitopatol. Bras., 24, 428-435, 1999. 